\title{
Sprawozdanie z międzynarodowej konferencji naukowej pt. Liturgia i polityka w wiekach średnich. Przeoczone dziedzictwo Ernsta H. Kantorowicza, Poznań, 13-14 VII 2017 r. ${ }^{1}$
}

Od 13 do 14 VII 2017 r. w Bibliotece Raczyńskich w Poznaniu odbyła się międzynarodowa konferencja naukowa poświęcona liturgii oraz polityce w wiekach średnich. Wydarzenie to zostało zorganizowanie przy współpracy Instytutu Historii Uniwersytetu im. Adama Mickiewicza w Poznaniu, Instytutu Historycznego Uniwersytetu Warszawskiego, Biblioteki Raczyńskich w Poznaniu oraz The PSALM-Network (Politics, Society, and Liturgy in the Middle Ages). Należy zaznaczyć, że konferencja oscylowała wokół spuścizny naukowej Ernsta H. Kantorowicza. Ten niemiecki historyk pochodzenia żydowskiego, który specjalizował się głównie w historii prawa i teologii politycznej średniowiecza, pozostawił po sobie wiele naukowych dzieł². Organizatorzy konferencji postanowili zwrócić uwagę na koncepcje i tezy E.H. Kantorowicza. Znamiennym jest także fakt wyboru miejsca konferencji, gdyż to właśnie w Poznaniu w 1895 r. ten niemiecki uczony przyszedł na świat.

Obrady zostały podzielone na pięć części. Pierwszego dnia można było wysłuchać referatów dotyczących metodologii E.H. Kantorowicza, I Rzeszy za czasów Ottonów i dynastii salickiej oraz późniejszego średniowiecza. Zaś drugiego dnia

\footnotetext{
1 Praca finansowania w ramach projektu Narodowego Centrum Nauki SYMFONIA 2, nr UMO-2014/12/W/NZ2/00466.

2 W Polsce do tej pory ukazały się jedynie dwa tłumaczenia dzieł E.H. Kantorowicza: Dwa ciała króla. Studium ze średniowiecznej teologii politycznej, przeł. M. Michalski, A. Krawiec, Warszawa 2007, ss. 483; tenże, Fryderyk II 1194-1250, przeł. G. Smółka, Oświęcim 2015, ss. 504.
} 
uczestnicy skupili się na słowiańskiej Europie, aby zakończyć konferencję zagadnieniami przeglądowymi.

Uczestników oraz gości przywitała dyrektor Biblioteki Raczyńskich w Poznaniu, Anna Gruszecka. Po niej oficjalnego otwarcia konferencji dokonał jeden z inicjatorów konferencji, dyrektor Instytutu Historii UAM, prof. dr hab. Józef Dobosz.

W pierwszej części spotkania zostały zaprezentowane trzy referaty. Jako pierwsza głos zabrała prof. Montserrat Herrero (Universidad de Navarrra), która swoje wystąpienie zbudowała wokół książki E.H. Kantorowicza „Laudes Regiae” (Aklamacja jako teologiczno-polityczny locus. Teoretyczne refleksje na temat ksiażki Kantorowicza pt.: Laudes Regiae). Następnie, prof. UAM dr hab. Adam Krawiec (UAM) zaprezentował recepcję „Dwóch ciał króla” we współczesnej humanistyce (Doktryna Kantorowicza. Drogi i bezdroża recepcji Dwóch Ciał Króla we współczesnej humanistyce). Ostatni referat w tej części programu dotyczył również tej samej książki E. H. Kantorowicza (Tempus, aeternitas i aevum w koncepcji Dwóch Ciał Króla Ernsta Kantorowicza), a wygłosił go prof. UAM dr hab. Maciej Michalski (UAM).

Drugą część konferencji rozpoczął prof. Stefano Manganaro (Università di Pavia), który dokonał rewizji „Dwóch Ciał Króla” w kontekście monarchii ottońskiej (Ottońskie królestwo chrystocentryczne. Rewizja The King's Two Bodies Kantorowicza po 60 latach). Postać Brunona z Toul jako przywódcę liturgicznego (Liturgiczny przywódca: Bruno z Toul (1026-1051) oraz jago liturgia biskupia utworzona dla klasztoru $w$ Moyenmoutier) przybliżył dr Pieter Byyttebier (Uniwersiteit Gent). Z kolei ostatni referent występujący w tej części, dr Paweł Figurski (UW) dokonał rewizji konceptu królestwa liturgicznego niemieckiego historyka (Kantorowicz i jego królestwo liturgiczne - rewizja konceptu).

Popołudniową sesję otworzył dr Jaume Aurell (Universidad de Navarra), który poruszył kwestie liturgii podczas koronacji królewskich w średniowieczu (Liturgia średniowiecznych koronacji. Perspektywa Kantorowicza). Ostatni referat tego dnia zaprezentował dr hab. Jerzy Pysiak (UW), który zwrócił uwagę na wywyższenie francuskiej monarchii w najstarszych zachowanych brewiarzach Saint-Chapelle (Najstarsze zachowane brewiarze Saint-Chapelle a wywyższenie francuskiej monarchii $w$ święto Korony Cierniowej). Po zakończeniu obrad uczestnicy konferencji mieli możliwość wzięcia udziału w wycieczce po Poznaniu (kierowali nią mgr Jakub Skutecki i prof. UAM dr hab. Maciej Michalski), odwiedzając miejsca związane z Ernstem Kantorowiczem.

Drugi dzień obrad rozpoczęła sesja poświęcona słowiańskiej Europie. O historii liturgii na ziemiach wczesnośredniowiecznej Rusi (Liturgiczna przeszłość na wcze- 
snośredniowiecznej Rusi) swój referat zaprezentowal prof. Sean Griffin (Westfälische Wilhems-Universität Münster). Po nim głos zabrał mgr Maksymilian Sas (UW), który wykorzystując badania komparatystyczne omówił problematykę źródeł liturgicznych i jej znaczenie w badaniach nad chrztem pierwszego władcy Polski (Co źródta liturgiczne wnosza do debaty na temat chrztu Mieszka I?). Z kolei prof. dr hab. Zbigniew Dalewski (PAN) poruszył kwestię stosunku pierwszych władców z dynastii piastowskiej do liturgii (Liturgiczne królestwo pierwszych Piastów).

Po przerwie na zgromadzonych czekały dwa referaty mające poniekąd charakter podsumowujący. Pierwszy z nich, autorstwa prof. Ryan'a Madisona (University of Notre Dame), dotyczył regulacji liturgicznych (Regulowanie liturgii: ekonomia, liturgia i państwo). Ostatni zaś z referentów, mgr Aleksander Sroczyński (UW) podjął się rozważań z pogranicza filologii i historii (Retoryka, reprezentacja oraz ciata polityczne). Następnie głos zabrali dr Paweł Figurski i prof. dr hab. Józef Dobosz, którzy dokonali oficjalnego zamknięcia oraz podsumowania konferencji.

Duże zainteresowanie konferencją, mimo wakacyjnego terminu, może wskazywać na to, jak ważne są badania nad dziełami zapomnianych naukowców, takich jak Ernst H. Kantorowicz. Organizatorzy zapowiedzieli kolejną konferencję poświęconą polityce i liturgii w wiekach średnich, która ma się odbyć w 2018 r.

mgr Jakub Wojtczak

Instytut Historii

Wydział Historyczny

Uniwersytet im. Adama Mickiewicza w Poznaniu

ul. Umultowska 89d

61-614 Poznań

kub.wojtczak@gmail.com 